\title{
Pendekatan intercultural communication pada public relations PT Santos dalam membangun komunikasi empati
}

\author{
Neng Yayu ${ }^{1}$, Anisti ${ }^{2}$, Dasrun Hidayat ${ }^{3}$, Mahardiansyah Suhadi ${ }^{4}$ \\ 1,2,3,4 Universitas BSI Bandung
}

\begin{abstract}
ABSTRAK
Fenomena yang diteliti tentang komunikasi yang dibangun oleh public relations PT Santos. Pada praktiknya komunikasi tidak berjalan baik sehingga diperlukan pendekatan khusus. Penelitian ini bertujuan untuk mengetahui pendekatan komunikasi antara public relations Santos dengan masyarakat Gili Genting Madura Provinsi Jawa Timur. Untuk menemukan tujuan tersebut, peneliti menggunakan metode kualitatif dengan studi etnografi public relations. Studi ini berfokus pada perilaku komunikasi untuk membangun hubungan. Dalam hal ini adalah komunikasi empati public relations dalam membangun hubungan dengan masyarakat Gili Genting. Teknik pengumpulan data melalui observasi dan wawancara mendalam yang melibatkan delapan orang informan. Adapun teori yang digunakan yaitu teori public relations budaya, komunikasi empati dan manajemen hubungan. Hasil penelitian mengungkapkan bahwa pendekatan komunikasi empati public relations PT Santos, dipengaruhi oleh budaya lokal. Budaya sebagai konteks komunikasi untuk memahami situasi masyarakat setempat. Hal ini dilakukan melalui kegiatan analisis situasi. Selanjutnya, public relations membuat perencanaan komunikasi meliputi pembuatan program, sosialisasi program, dan evaluasi program. Pendekatan yang dilakukan melalui keterlibatan secara langsung dengan kegiatan masyaraat. Public Relations menyesuaikan diri, melakukan adaptasi dengan lingkungan setempat. Penyesuaian meliputi bahasa dan gaya berpakaian. Hal ini sangat membantu perolehan data yang dapat dijadikan sebagai dasar pembuatan dan sosialisasi program. Keterlibatan diri dengan menposisikan sebagai anggota masyarakat setempat merupakan bagian dari upaya komunikasi empati yang dibangun oleh public relations. Komunikasi ini dilandasi oleh rasa percaya dan keterbukaan sehingga dapat membangun relasi budaya.
\end{abstract}

Kata-kata Kunci: Intercultural communication; komunikasi empati; relasi budaya; komunikasi; public relations

\section{Intercultural communication approach by PT. Santos public relations in building empathic communication}

\begin{abstract}
The research is focusing on communication performed by Public Relations of PT Santos. In practice, communication does not work well, so an individual approach is needed. This study aims to determine the communication approach between PT Santos Public Relations and the Gili Genting Madura community in East Java Province. To find these objectives, researchers used qualitative methods with ethnographic studies of public relations centering on communication behavior in building relationships. In this case, emphatic communication. The data collection techniques are through observation and in-depth interviews involving eight informants. The theories used are the theory of cultural Public Relations, empathic communication, and relationship management. The results revealed that the empathic communication approach of PT Santos's public relations influenced by local culture. Empathic communication is done through the activities of the situation analysis. Furthermore, the Public Relations department creates communication planning, including program making, program socialization, and program evaluation. Public Relations adapts, through the local environment by carrying out through direct involvement with community activities. Adjustments include language and style of dress, a beneficial way to obtain data that can be used as a basis to create a program and socialization. Self-involvement by positioning as a member of the local community is part of an empathic communication effort built by public relations. This communication is based on trust and openness to generate excellent cultural relations.
\end{abstract}

Keywords:Intercultural communication; empathy communication;cultural relations; communication; public relations

Korespondensi: Neng Yayu. Universitas BSI Bandung. Antapani, Jl. Terusan Sekolah No.1-2, Cicaheum, Kec. Kiaracondong, Kota Bandung, Jawa Barat 40282.Email: neng.ayuka@gmail.com 


\section{PENDAHULUAN}

Terciptanya hubungan baik antara perusahaan dengan masyarakat sekitar merupakan wujud keberhasilan public relations dalam menjalankan peran serta mengoptimalkan fungsinya. Salah satu peran public relations adalah menjadi fasilitator komunikasi (Hidayat, 2014). Public Relations (PR) sebagai fasilitator berupaya untuk menjembatani setiap informasi yang diperlukan oleh perusahaan yang bersumber dari masyarakat, demikian pula sebaliknya informasi dari perusahaan untuk masyarakat. Dalam penelitian ini, public relations yang dimaksud adalah public relations PT.Santos sebuah perusahaan yang bergerak di bidang Minyak Bumi dan Gas. Perusahaan ini terletak di Desa Gili Genting dengan daerah operasionalnya di laut Madura. Perusahaan ini seringkali mendapatkan penolakan dari masyarakat setempat. Hal ini terjadi karena masyarakat yang berprofesi sebagai nelayan, menduga keberadaan PT Santos akan merusak laut sehingga pada akhirnya merugikan mata pencaharian mereka.

Fenomena tersebut menjadi latar belakang bagi penelitian ini. Adanya penolakan dari masyarakat ini mengedepankan peran public relations untuk mampu mempertemukan keinginan antara perusahaan PT Santos dengan masyarakat terdampak yakni masyarakat
Gili Genting Madura. Public Relations sebagai jembatan penghubung dalam sebuah komunikasi antara perusahaan dengan masyarakat, diharapkan mampu menjadi jalan bagi keduanya. Dalam upaya membangun komunikasi maka diperlukan komunikasi dengan pendekatan budaya atau intercultural communication. Hal senada diungkapkan Jandt, bahwa budaya sebagai konteks utama dalam berkomunikasi (Jandt, 2013). Dalam konteks ilmu public relations, kajian public relations dengan pendekatan teori budaya disebut Public Relations Budaya atau PR Budaya (Hidayat, Kuswarno, \& Zubair, 2017). Teori public relations budaya menjelaskan bahwa semua aktivitas public relations selalu dipengaruhi oleh budaya. Misalnya, pada saat public relations akan melakukan kegiatan Corporate Social Responsibility (CSR) maka sebaiknya public relations memperhatikan faktor-faktor budaya masyarakat setempat sebagai sasaran kegiatan. Adanya keterlibatan pemahaman terhadap budaya diharapkan dapat membantu pelaksanaan sehingga tujuan kegiatan dapat tercapai sesuai dengan rencana awal. Teori public relations budaya memiliki asumsi bahwa budaya sebagai mata rantai kegiatan public relations, dan budaya sebagai landasan dasar kegiatan public relations.

Public Relations mempunyai peranan yang sangat penting dalam perusahaan. Tidak saja 
berfungsi menyampaikan informasi kepada publik, akan tetapi juga mengedukasi dengan memberikan pemahaman tentang produk perusahaan. Demikian pula dengan peran public relations PT Santos yang selalu membantu proses operasional di lapangan. Peran yang dilakukan yakni memberikan penyuluhan kepada masyarakat setempat. Hal ini dilakukan untuk memberikan pemahaman agar masyarakat tidak menganggap keberadaan PT Santos sebagai ancaman. Untuk mendapatkan hasil yang maksimal, maka peran public relations harus dilakukan secara terencana dan terarah. Hal ini selaras dengan pendapat, Cutlip (dalam Morrisan, 2008) bahwa public relations harus melakukan, the planned effort to influence opinion throught good character and responsible performance, based on mutually satisfactory two-way communications. Artinya, bahwa setiap public relations seyogyanya melakukan usaha terencana untuk memengaruhi pandangan melalui karakter yang baik serta tindakan yang bertanggung jawab, didasarkan atas komunikasi dua arah yang saling memuaskan. Dalam keterkaitan dengan penelitian ini, peneliti ingin mengetahui bagaimana peran public relations PT Santos dalam merencanakan, mempertimbangkan, menjalankan, memutuskan, serta menjelaskan tentang perusahaan dan kegiatan operasionalnya di lapangan. Bagaimana public relations PT
Santos berusaha memahami karakter sosial budaya masyarakat Madura, dan bagaimana public relations PT Santos menerapkan komunikasi baik dalam kegiatan sosialisasi pada masyarakat terdampak?. Beragam pertanyaan tersebut, tentu saja penting untuk dikaji sebagai aspek dari tujuan penelitian. Dengan demikian, dapat diketahui pendekatan komunikasi yang digunakan public relations $\mathrm{PT}$ Santos dalam upaya memberikan pemahaman dan membangun dukungan dari masyarakat Gili Genting Madura.

Adapun fungsi manajemen public relations terkait dalam membangun hubungan baik, meliputi empat proses yaitu penelitian, perancanaan, pelaksanaan, dan evaluasi. Hal ini selaras dengan teori strategi manajemen bahwa setiap public relations berkontribusi pada beberapa kegiatan manajemen meliputi (a) penelitian reguler, (b) penelitian untuk menjawab pertanyaan spesifik, (c) pendekatan formal lainnya untuk mengumpulkan informasi, (d) pendekatan informal untuk mengumpulkan informasi, (e) kontak dengan orang yang berpengetahuan di luar organisasi, dan (f) penilaian berdasarkan pengalaman (Grunig, 2010). Strategi manajemen tersebut juga ditetapkan sebagai aturan PT Santos dalam mengelola peran dan fungsi public relations. Public Relations PT Santos yang terlibat dalam pengelolaan informasi 
yaitu Team Leader, Community Relations, dan Community Relations. Mereka saling berkoordinasi dalam memecahkan persoalan di lapangan. Tiga fungsi pokok public relations dalam organisasi berdasarkan pernyataan Bertrand, (dalam Gassing \& Suryanto, 2016) pertama mengabdi pada kepentingan publik. Kedua, memelihara komunikasi yang baik, dan ketiga menitikberatkan pada aspek moral dan etika. Hal ini selaras dengan asal-usul teori public relations bahwa public relations dilatar belakangi oleh teori dialogis, teori tindakan komunikatif Hubermas, dan teori etika komunikasi (Wirtz \& Zimbres, 2018). Teori dialogis yang mengutamakan aspek komunikasi dua arah sehingga dinilai lebih efektif dalam membangun hubungan.

Dalam menjalankan fungsinya, public relations semestinya menggunakan pendekatan budaya. Pulic Relations menempatkan budaya sebagai aspek utama dalam memahami perilaku komunikasi masyarakat. Hal senada dipertegas (Sriramesh dalam Hidayat et al., 2017), bahwa budaya dan public relations merupakan satu mata-rantai yang erat dan saling berkaitan. Budaya sebagai pintu gerbang dalam memahami perilaku komunikasi. Demikian halnya public relations $\mathrm{PT}$ Santos dalam memahami budaya lokal masyarakat Gili Genting. Budaya dapat menjadi sebuah pendekatan yang mampu membawa masyarakat untuk lebih mudah menerima keberadaan perusahaan. Budaya dapat dijadikan sebagai senjata karena budaya dianggap sebagai nilai-nilai dan keyakinan yang dimiliki setiap masyarakat. Pendekatan kerja public relations berbasis budaya dapat dijadikan sebagai cara kerja public relations. Terlebih dengan kondisi Indonesia yang kaya akan budaya. Adanya budaya tentu saja membawa pada perbedaan dalam sikap dan berperilaku. Untuk itu, budaya sangat tepat digunakan sebagai pendekatan kerja public relations dalam menghadapi dunia global. Public Relations efektif adalah yang mampu memahami budaya dengan berpikir global dan bertindak global (Ming-Yi dalam Hidayat et al., 2017).

Di era globalisasi saat ini budaya dapat dipelajari melalui proses belajar. Diantara cara mempelajari budaya yakni melalui empati. Berusaha menempatkan diri dengan melibatkan diri secara langsung di dalam kelompok masyarakat. Empati disini adalah kemampuan kognitif untuk memahami kondisi mental dan emosional orang lain. Inti dari komunikasi empati yakni pemahaman terhadap perasaan orang lain secara mendalam. Empatik artinya menempatkan diri pada posisi orang lain.Ikut serta secara emosional dan intelektual dalam pengalaman orang lain(Rakhmat dalam Ibrahim, 2004). Sedangkan, kemampuan berempati adalah kemampuan untuk mengetahui perasaan 
orang lain. Empati merupakan akar kepedulian dan kasih sayang dalam setiap hubungan emosional seseorang. Menurut Makmun, kunci untuk memahami perasaan orang lain adalah mampu membaca pesan non-verbal seperti nada bicara, gerak- gerik, ekspresi wajah, dan sebagainya (Goleman dalam Makmun, 2013). Empati sebagai sebuah ciri penting dari kecerdasan emosional. Mempunyai rasa empati tidak berarti bahwa seseorang setuju dengan orang lain, akan tetapi hal ini semata-mata menunjukkan bahwa seseorang menghargai dan mendukung sudut pandang orang lain.Empati bukan sekadar komponen penting, tetapi juga merupakan komponen paling mendasar dari sebuah mindset berdaya tahan (Makmun, 2013).

Pada dasarnya empati sangat membantu terjadinya komunikasi persuasi yaitu komunikasi yang bertujuan untuk mengajak bahkan mempengaruhi oranglain. Sebagai proses sosial, komunikasi selalu dijumpai di setiap saat. Namun, tidak semua komunikasi mampu dilakukan secara persuasif. Untuk itu, diperlukan tindakan empati dalam berkomunikasi. Tindakan empati diharapkan dapat mempermudah tercapainya tujuan komunikasi. Menurut Effendy, komunikasi bertujuan untuk (1) mengubah sikap, (2) mengubah opini, (3) mengubah perilaku, (4) dan pengubah masyarakat (Effendy dalam Sentosa, 2015). Perilaku empati merupakan strategi penting dalam sebuah proses perencanaan kegiatan public relations PT Santos di lapangan. Pentingnya memahami empati dalam sebuah proses interaksi pada masyarakat yang masih sangat kental akan budayanya. Pemahaman tersebut dapat menjadikan nilai tambah pada masyarakat Gili Genting terhadap usaha public relations PT Santos dalam menyatukan perusahaan dengan masyarakat.

Melalui komunikasi empati dengan pendekatan budaya, diharapkan pesan perusahaan dapat tersampaikan sepenuhnya kepada masyarakat. Memahami perasaan secara mendalam merupakan suatu bentuk nilai tinggi pada proses membangun hubungan baik. Keterlibatan public relations PT Santos dalam kegiatan masyarakat menjadi acuan dasar dalam praktik komunikasi empati yang bertujuan untuk membangun hubungan baik. Inti dari interaksi empati ini merupakan keterlibatan secara langsung untuk memahami perasaan orang lain secara mendalam. Salah satu prasyarat utama dalam memiliki sikap empati adalah kemampun untuk mendengarkan atau mengerti terlebih dulu sebelum didengarkan atau dimengerti oleh orang lain (Hidayat, 2012). Berdasarkan pemaparan latar belakang penelitian, maka artikel ini fokus mengkaji tentang komunikasi empati public relatons PT Santos dalam membangun hubungan baik dengan masyarakat Gili Genting Madura sebagai masyarakat 
terdampak.

\section{METODE PENELITIAN}

Penelitian ini menggunakan pendekatan kualitatif dengan paradigma konstruktivis. Kualitatif merupakan penelitian yang menempatkan peneliti berada di dalam masalah penelitian sehingga terbangun keterlibatan langsung didalamnya. Pada praktiknya, peneliti melakukan studi lapangan (field work) melalui partisipasi dalam setiap kegiatan masyarakat Gili Genting. Secara epistimologis penelitian ini erat dengan teknik observasi dan wawancara mendalam yang melibatkan masyarakat Gili Genting sebagai masyarakat terdampak dan PT Santos sebagai pengelola. Hasil data wawancara diolah melalui teknik analisis data meliputi reduksi, display dan penarikan kesimpulan data. Sebelum ditarik kesimpulan data diuji terlebih dahulu dengan mengguakan teknik otentitas data yaitu triangulasi data mencakup waktu wawancara yang diulang, mencocokkan data melalui sumber data yang berbeda dan menggunakan beberapa referensi sebagai bahan konfirmasi data terhadap teori-teori relevan.

Untuk menjawab tujuan penelitian, peneliti juga menggunakan studi etnografi public relations yakni studi yang fokus pada perilaku komunikasi untuk membangun hubungan. Etnografi public relations menekankan pada komponen perencanaan komunikasi dalam setiap aktivitas public relations yang bertujuan tidak hanya memahami perilaku komunikasi, akan tetapi menggali pola hubungan yang dibangun atas dukungan publik. Komponen studi etnografi public relations meliputi Insight, Program Strategic, Program Implementation, Action and Reputation atau IPPAR Model (Hidayat \& Suhartini, 2018).

Insight adalah tahapan awal dalam memetakan atau melakukan analisis situasi Tahapan ini bertujuan untuk memahami situasi yang melatarbelakangi aktivitas budaya. Insight juga dimaksudkan untuk menetapkan setting publik sebagai sasaran dan tujuan utama kegiatan public relations (objectives). Tahapan analisis data berikutnya menetapkan perencanaan (program strategic) yakni menjelaskan tentang jenis kegiatan, tema, isi pesan, strategi penyampaian pesan, dan media yang digunakan. Pada tahapan terakhir yaitu pelaksanaan kegiatan (program implementation) yang bertujuan menjalankan semua aktivitas public relations sesuai dengan aturan atau ketentuan yang telah ditetapkan. Tahapan ini merujuk pada nada, cara bertutur, bahasa, perilaku dan etika dalam menyampaikan pesan. Analisis data selanjutnya yaitu mengukur penilaian publik (action). Hal ini dapat diketahui melalui evaluasi kegiatan sehingga diketahui respons dan dukungan publik sebagai tolak ukur reputasi (reputation) atas kegiatan public 
Tabel 1 IPPAR Model: Komponen Etnografi Public Relations

\begin{tabular}{|c|c|c|c|}
\hline IPPAR & & Definsi & Penjelasan \\
\hline I- Insight & & $\begin{array}{l}\text { - Berkenaan dengan analisis } \\
\text { situasi, pengumpulan data terkait } \\
\text { dengan aktivitas komunikasi } \\
\text { budaya. } \\
\text { - Waktu dan tempat } \\
\text { aktivitas komunikasi budaya } \\
\text { berlangsung, situasi psikologis } \\
\text { pembicaraan, sasaran kegiatan, } \\
\text { audience. } \\
\text { pihak yang teribat dalam aktivitas } \\
\text { komunikasi budaya. }\end{array}$ & $\begin{array}{l}\text { - Analisis situasi berkaitan dengan } \\
\text { persiapan pada setiap aktivitas } \\
\text { komunikasi budaya. } \\
\text { - Menekankan pada situasi fisik } \\
\text { dan psikologis, tempat, audience } \\
\text { atau pihak terkait dalam aktivitas } \\
\text { komunikasi budaya. Misal, } \\
\text { pembicaraan pada musyawarah } \\
\text { mufakat, mufakat adat berbeda } \\
\text { dengan obrolan sehari-hari, } \\
\text { mulai dari seting waktu, tempat } \\
\text { dan pihak yang terlibat di dalam } \\
\text { kegiatan. }\end{array}$ \\
\hline $\begin{array}{l}\mathrm{P}-\text { Public } \\
\text { Strategic }\end{array}$ & ogram & $\begin{array}{l}\text { - Berkaitan dengan jenis kegiatan, } \\
\text { tema, pesan budaya yang akan } \\
\text { disampaikan. } \\
\text { - Mengacu bentuk pesan } \\
\text { berkenaan dengan dengan kata } \\
\text { yang digunakan, bagaimana } \\
\text { penggunaannya. } \\
\text { - Isi pesan berkenaan dengan } \\
\text { hubungan antara apa yang } \\
\text { dikatakan dengan topik } \\
\text { pembicaraan. }\end{array}$ & $\begin{array}{l}\text { - Kegiatan komunikasi budaya } \\
\text { mempengaruhi strategi kegiatan } \\
\text { berupa jenis, bentuk dan isi pesan. } \\
\text { - Misalnya kegiatan upacara adat } \\
\text { pernikahan tentu saja berbeda isi } \\
\text { pesan dan topik pembicaraannya } \\
\text { dengan percakapan biasa. }\end{array}$ \\
\hline $\begin{array}{l}\mathrm{P}-\text { Public relations } \\
\text { Implementation }\end{array}$ & ogram & $\begin{array}{l}\text { - Berkenaan dengan } \\
\text { pelaksanaan aktivitas komunikasi } \\
\text { budaya. } \\
\text { - Mengacu pada nada, cara, } \\
\text { dan semangat di mana suatu pesan } \\
\text { disampaikan. } \\
\text { - Mengacu pada jalur } \\
\text { bahasa yang digunakan dan juga } \\
\text { mengacu pada kode ujaran yang } \\
\text { digunakan. } \\
\text { atau aturan dalam berinteraksi dan } \\
\text { juga mengacu pada penafsiran } \\
\text { terhadap ujaran dari lawan bicara. } \\
\text { - Mengacu pada jenis } \\
\text { bentuk penyampaian }\end{array}$ & $\begin{array}{l}\text { - Dengan senang hati, } \\
\text { dengan serius, dengan singkat, } \\
\text { dengan sombong, dengan } \\
\text { mengejek dan sebagainya. Atau } \\
\text { dapat ditunjukkan juga dengan } \\
\text { gerak tubuh dan isyarat. } \\
\text { Jalur tulisan, lisan, } \\
\text { melalui telegraf atau telepon, } \\
\text { bahasa, dialek, fragam atau } \\
\text { register. } \\
\text { - Berhubungan dengan } \\
\text { cara berinterupsi, cara bertanya, } \\
\text { dan sebagainya. } \\
\text { Narasi; puisi, pepatah, } \\
\text { doa, dan sebagainya. }\end{array}$ \\
\hline $\mathrm{A}-$ Action & & $\begin{array}{l}\text { - Audit persepsi publik. } \\
\text { - Penilaian, respons publik. }\end{array}$ & $\begin{array}{l}\text { - Penilian publik terhadap } \\
\text { aktivitas komunikasi berupa citra } \\
\text { budaya atas relasi budaya yang } \\
\text { terbangun. }\end{array}$ \\
\hline $\mathrm{R}-$ Reputation & & $\begin{array}{l}\text { - Kepercayaan dan dukungan } \\
\text { publik terkait dengan sekumpulan } \\
\text { citra tentang relasi budaya. }\end{array}$ & $\begin{array}{l}\text { - Hasil akhir dari aktivitas } \\
\text { komunikasi; } \\
\text { dukungan membangun } \\
\text { terbangun pola relasi budaya. }\end{array}$ \\
\hline
\end{tabular}

Sumber: Hidayat, Kuswarno, Zubair, \& Hafiar, 2018

relations. Komponen etnografi public relations mengacu pada komponen analisis data etngorafi komunikasi Dell Hymes yakni SPEAKING meliputi Situation, Participants, Ends, Act squences, Key, Instumentalitis, Norms dan Genres (Hidayat \& Suhartini, 2018). Etnografi public relations sebagai studi mengutamakan data primer sehingga peneliti sering melakukan 
observasi dan wawancara dengan informan. Diharapkan data primer dapat menjawab konsep penelitian kualitatif yang lebih menekankan pada kedalaman hasil penelitian. Penelitian merupakan kegiatan ilmiah yang berkaitan dengan analisis dan konstruksi yang dilakukan secara metodelogis, sistematis dan konsisten (Ruslan, 2015). Teknik pengumpulan data merupakan proses terpenting dalam penelitian ini, sehingga peneliti melakukan beberapa tahapan dan cara untuk pengambilan data yang dibutuhkan untuk proses penelitian agar dapat memperkuat analisis dan mempermudah proses penelitian, yaitu terdiri dari: a) pra-riset, yaitu melakukan pengamatan awal untuk menggali dan memahami data hingga ditemukan fokus masalah penelitian. b) setelah menemukan fokus penelitian selanjutnya peneliti merancang proposal sebagai acuan pada saat penelitian. c) pada tahapan berikutnya melakukan penelitian, d) mengolah data, dan e) membuat laporan hasil penelitian.

\section{HASIL DAN PEMBAHASAN}

Berdasarkan hasil penelitian, ditemukan bahwa masyarakat Gili Genting Madura memiliki karakter sosial budaya yang kuat. Watak dan sifat khas orang Madura dipengaruhi oleh banyak hal, seperti kondisi alam yang dilalui dengan perjuangan yang keras (Ma'arif,
2015). Hal ini mempengaruhi sulitnya mencari penghidupan karena sumber daya alam terbatas. Adapun ciri khas dari masyarakat Madura yaitu kebudayaan yang masih sangat kental hingga saat ini. Beberapa bentuk kepercayaan masyarakat Madura, seperti haji sebagai tujuan hidup mereka, Karapan Sapi, Saronen, dan terhadap hal yang berbau magis yaitu ritual Pethik Laut atau Rokat Tasse (sama dengan larung sesaji). Penjelasan diatas menggambarkan secara singkat tentang karakter sosial masyarakat Madura sebagai subjek penelitian yang sangat kuat memegang nilai budaya lokal.

Dilihat dari fenomena sejarah tentang karakteristik sosial budaya masyarakat Madura, sangat tidak mudah bagi seorang public relations untuk menjalankan suatu perannya di lapangan. Menghadapi karakter masyarakat yang masih menjunjung tinggi nilai budaya lokal, dapat dipastikan akan bersinggungan dengan keyakinan mereka. Sehingga pada akhirnya public relations mengalami kendala ketika masyarakat terdampak yaitu masyarakat Gili Genting Madura tidak dapat bekerjasama dengan baik. Namun demikian, situasi tersebut justru yang mendorong PT Santos dalam waktu kurang lebih 10 tahun ini berusaha membuat program sosialisasi dan penyuluhan kepada masyarakat setempat. Kegiatan ini merupakan strategi sekaligus tanggung jawab public relations PT Santos. Adapun strategi 
yang digunakan yaitu melakukan perubahan pendekatan seorang praktisi public relations di lapangan. Dengan melakukan perubahan pendekatan tersebut, masyarakat merasakan adanya perbaikan di bandingkan dengan sebelumnya. Pendekatan yang dimaksud adalah pendekatan berperanserta, atau dalam istilah masyarakat lokal yaitu gotong-royong. Artinya bahwa adanya keterlibatan secara langsung public relations dengan kegiatan masyarakat setempat. Melalui pendekatan ini public relations akan lebih mudah memahami karakter informan sehingga mereka dapat menerima keberadaan PT Santos. Penerimaan tersebut didasari tidak adanya kecurigaan karena adanya keterbukaan. Namun, hal tersebut tidak dapat dibangun tanpa adanya pendekatan secara langsung dan melebur dengan masyarakat setempat.

Selama proses penelitian, peneliti mengamati secara langsung kegiatan-kegiatan yang dilakukan oleh Public Relations ekstrnal PT Santos. Tugas utama yang dilakukan oleh public relations PT Santos di lapangan adalah menjalin hubungan baik. Tugas tersebut berupa sosialisasi tentang PT Santos kepada masyarakat terdampak. Kegiatan-kegiatan yang dilakukan oleh public relations selama di lapangan dalam berinteraksi dengan masyarakat terdampak, diantaranya pendekatan kerjasama dengan Lembaga Swadaya Masyarakat (LSM)
BISMA. LSM ini lebih banyak mengetahui karakter sosial budaya masyarakat Madura sehingga diharapakan BISMA dapat membantu dalam membangun dan menjalin hubungan baik dengan masyarakat terdampak khususnya pada masyarakat Kecamatan Gili Genting, Kabupaten Sumenep, Madura. Kegiatan sosialisasi bersama LSM tersebut diantaranya a). Mengunjungi para tokoh masyarakat dan kepala desa yang berada di wilayah terdampak dengan melakukan sosialisasi atau silaturahmi yang disebut dengan Triwulan (Tiga Bulan Sekali).Pesan komunikasi yang dibahas yaitu tentang kondisi masyarakat terdampak. Suasana yang dibangun sangat santai, yakni bincangbincang seputar pandangan masyarakat tentang PT Santos. Para tokoh masyarakat mengungkapkan semua keluhan masyarakat terdampak, khususnya masyarakat nelayan. b) Pendekatan berikutnya yakni menyesuaikan gaya hidup dengan masyarakat setempat. Pada saat melakukan sosialisasi, public relations PT Santos menanggalkan segala bentuk kemewahan yang biasa ada dilingkungan kerja. Pada saat sosialisasi, public relations PT Santos mengenakan pakaian yang sangat sederhana seperti beralaskan sandal, baju kaos, dan tanpa menggunakan kendaraan mobil ketika mendatangi masyarakat. Pendekatan ini dilakukan agar tidak ada penghalang atau jarak yang membatasi antara public relations sebagai 
representasi PT Santos dengan masyarakat terdampak. Adanya kesamaan dalam gaya berpakaian tentu akan lebih mudah untuk berbaur dengan masyarakat setempat. c). Pendekatan selanjutnya yaitu menunjukkan rasa bersaudara kepada masyarakat terdampak, seperti menjenguk salah satu keluarga mereka yang sedang sakit, atau melayat bagi anggota keluarganya yang meninggal dengan tujuan untuk memberikan santunan kepada keluarga yang tengah berduka. d). Aktif berkontribusi dalam kegiatan budaya masyarakat Madura, seperti halnya dalam kegiatan Petik Laut atau Rokat Tasse, dan Karapan Sapi. Pengertian dari Petik Laut atau Rokat Tasse ini merupakan peristiwa ritual yang dilakukan para nelayan sebagai bentuk rasa syukur kepada yang maha kuasa karena telah memberikan limpahan hasil ikan tangkapan di laut. Sedangkan karapan sapi ini merupakan acara tahunan paling terkenal di Madura.

Keberhasilan public relations PT Santos dalam melakukan sosialisasi kepada masyarakat karena adanya itikad baik yaitu berupa "empati”. Public Relations dengan teknik komunikasi secara langsung, ia berusaha untuk berbaur dan mencoba memahami karakter masyarakat setempat. Makmun menyatakan bahwa empati tidak berarti bahwa seseorang setuju dengan orang lain, akan tetapi hal ini semata-mata menunjukkan bahwa seseorang menghargai dan mendukung sudut pandang orang lain (Makmun, 2013). Adanya pembauran tersebut sehingga membantu penerimaan keberadaan PT Santos. Tentu saja sebelum pesan yang akan disampaikan, terlebih dahulu yang penting diyakinkan adalah bahwa keberadaan public relations $\mathrm{PT}$ Santos dipastikan dapat diterima oleh masyarakat. Pada tahapan berikutnya baru berbicara tentang pesan atau misi dari perusahaan. Upaya public relations PT Santos untuk berempati dengan masyarakat setempat telah berhasil membuka jalan sosialisasi program PT Santos. Komunikasi empati yang ditunjukkan oleh public relations PT Santos juga berhasil membantu dalam memahami gaya berbicara masyarakat setempat. Dari hasil pengamatan, gaya komunikasi terlihat sepele, akan tetapi dapat memicu hubungan tidak baik antar kedua belah pihak. Hal yang perlu dihindari pada saat berkomunikasi yaitu tidak berkomentar pada saat musyawarah, memotong pembicaraan, menyimak dengan sebelah pihak, bahasa tubuh yang terlihat tidak nyaman, dan sebagainya. Karakter lokal ini dapat merusak proses komunikasi, apabila tidak dipelajari dan dipahami oleh seorang praktisi public relations.

Tahapan pengenalan tentang karakter masyarakat Gili Genting Madura dapat diartikan sebagai upaya perencanaan. Dalam hal ini, artinya bahwa public relations PT Santos berhasil dalam melakukan analisis situasi terkait 
dengan latar belakang masyarakat setempat. Hal tersebut senada dengan teori public relations, bahwa public relations harus membuat perencanaan agar kegiatan lebih terarah Cutlip (dalam Morrisan, 2008). Diperkuat kembali hasil penelitian Hidayat bahwa setiap aktivitas public relations membutuhkan perencanaan komunikasi, di dalamnya terdapat analisis situasi yang dimaksudkan untuk memahami latar belakang "insight" dari rencana kegaitan (Hidayat et al., 2017). Adanya tahapan perencanaan diharapkan tujuan kegiatan akan lebih masksimal. Perencanaan artinya bahwa proses kegiatan public relations sudah melibatkan unsur masyarakat sebagai khalayak.

Mencoba untuk memahami psikologi khalayak sama halnya dengan berempati sebelum berkomunikasi. Dengan demikian, diharapkan dapat membentuk rasa saling pengertian, menumbuhkan persahabatan, memelihara kasih sayang sehingga mampu membangun kepercayaan. Kepercayaan masyarakat akan tumbuh ketika adanya unsur keterbukaan. Untuk itu, fungsi utama dari public relations adalah memberikan pemahaman untuk membangun kepercayaan publik (Hidayat, 2014). Kepercayaan adalahmodal dalam membangun hubungan baik. Dalam hal ini, hubungan public relations PT Santos dengan masyarakat Gili Genting Madura sebagai masyarakat terdampak perusahaan minyak PT
Santos.

Hubungan baik sebagai hasil dari komunikasi empati yang dibangun oleh public relations PT Santos senantiasa menggunakan pendekatan budaya. Hal ini sangat disadari oleh public relations $\mathrm{PT}$ Santos karena budaya dinilai sebagai konteks utama dalam berkomunikasi Budaya merupakan objek material dan komunikasi sebagai proses mentransmisikan nilai-nilai budaya adalah objek formal. Hal ini senada diungkapkan Jandt bahwa budaya tidak dapat lepas dari komunikasi karena budaya sebagai konteks dalam berkomunikasi (Jandt, 2013). Dengan demikian, faktor utama yang perlu diperhatikan ketika akan melakukan komunikasi adalah memahami terlebih dahulu budaya masyarakat Gili Genting Madura. Public Relations PT Santos yang senantiasa memposisikan diri sebagai bagian dari masyarakat terdampak.

Hubungan baik antara masyarakat Gili Genting Madura sebagai masyarakat terdampak dengan PT Santos, juga terbangun karena teknik komunikasi empati yang dilakukan secara langsung atau tatap muka. Menurut Jandt, komunikasi face to face sangat persuasif dibandingkan komunikasi bermedia (Jandt, 2013). Komunikasi tatap muka dapat menangkap nilai-nilai budaya dari lawan berbicara. Komunikasi langsung dapat membangun keakraban karena adanya 
proses transmisi nilai-nilai secara langsung. Demikian pula komunikasi empati yang dibangun public relations PT Santos selalu mengedepankan pertemuan tatap muka. Hal ini senada dengan pengakuan informan, bahwa komunikasi tatap muka, dirasakan lebih mudah dalam memberikan pemahaman, dibandingkan menggunakan media. Ditambah karakter masyarakat setempat yang sensitif sehingga komunikasi bermedia sangat membuka peluang terjadinya kesalahpahaman. Untuk itu, public relations PT Santos senantiasa menerapkan teknik komunikasi langsung agar dapat mengurangi kesalahpahaman.

Pada praktiknya, aktivitas public relations tidak dapat dilakukan tanpa adanya komunikasi karena komunikasi sebagai tulang punggung aktivitas public relations (Ardianto, 2013). Dalam upaya menciptakan suatu hubungan baik, tentunya diperlukan strategi komunikasi. Secara historis public relations menempatkan komunikasi sebagai aspek utama. Hal ini terjadi sejak revolusi industri di negara barat dan eropa (Rodríguez-salcedo \& Gómezbaceiredo, 2017). Terciptanya suatu hubungan kerjasama yang harmonis, saling memahami dan menghargai satu sama lainnya dalam suatu ruang lingkup yang sama antara perusahaan dengan stakeholder. Karenanya, pentingnya kehadiran komunikasi di dalam setiap aktivitas public relations. Sebagai contoh dalam suatu hubungan, baik itu dengan keluarga, lingkungan masyarakat, dan lembaga atau instansi kerja, ada diantara karyawan atau anggota keluarga yang tidak saling menyapa saat bertemu, tidak tersenyum saat berpapasan, tidak menanggapi apapun saat lawan bicara sedang berbicara. Situasi seperti ini akan merusak hubungan yang sebelumnya sudah terbangun. Oleh karena itu, kemampuan manusia dalam berkomunikasi secara empati sangat diperlukan sebagai upaya membangun dan memupuk hubungan baik. Bahkan akhir-akhir ini, kemampuan komunikasi empati semakin dibutuhkan untuk memperbaiki berbagai kegagalan komunikasi antar pribadi, komunikasi kelompok, komunikasi organisasi, komunikasi sosial ataupun komunikasi antara budaya, yang tidak jarang dalam kehidupan sehari-hari telah menyulut kesalahpahaman.

Public Relations PT Santos, selalu berusaha menjalin dan menciptakan hubungan baik dengan stakeholder yang berada di lingkungan terdampak operasional PT Santos. Usaha melalui komunikasi empati dengan menggunakan pendekatan intercultural communication. Hal ini dinilai berhasil dalam menanamkan kepercayaan masyarakat. Public Relations PT Santos selaku jembatan penghubung antara perusahaan dengan stakeholder juga selalu ikut serta berkontribusi dalam melestarikan budaya masyarakat di Kecamatan Gili Genting Madura, Kabupaten Sumenep Jawa Timur. Selain itu, 
public relations $\mathrm{PT}$ Santos selalu memperhatikan budaya lokal sebagai bahan pertimbangan dalam bertindak. Aktivitas public relations PT Santos juga senantiasa menyesuaikan konteks budaya lokal. Temuan ini yang memperkuat bahwa penelitian ini termasuk pada kajian Public Relations Budaya atau PR Budaya. Kajian yang berfokus pada aktivitas public relations dengan pendekatan teori budaya (Hidayat \& Suhartini, 2018). Aktivitas public relations PT Santos senantiasa mengedepankan nilai budaya di dalam setiap kegiatan sosialisasi program PT Santos. Berikut ini adalah hasil temuan peneliti terkait dengan tahapan pendekatan komunikasi empati public relations PT Santos dengan masyarakat terdampak. Komunikasi empati bertujuan untuk membangun hubungan baik antara PT Santos dengan masyarakat setempat. Pada praktiknya diperlukan peran seorang public relations untuk melakukan pendekatan kepada masyarakat. Pendekatan public relations $\mathrm{PT}$ Santos menggunakan pendekatan intercultural communication, yakni mejadikan budaya lokal sebagai konteks dalam perencanaan komunikasi. Perencanaan tersebut meliputi analisis situasi yang bertujuan untuk mengetahui situasi masyarakat, karakter dan kebiasaan mereka. Hal ini penting sebagai acuan dalam membuat program strategik. Dalam pelaksanaan program tersebut public relations PT Santos mengggunakan teknik

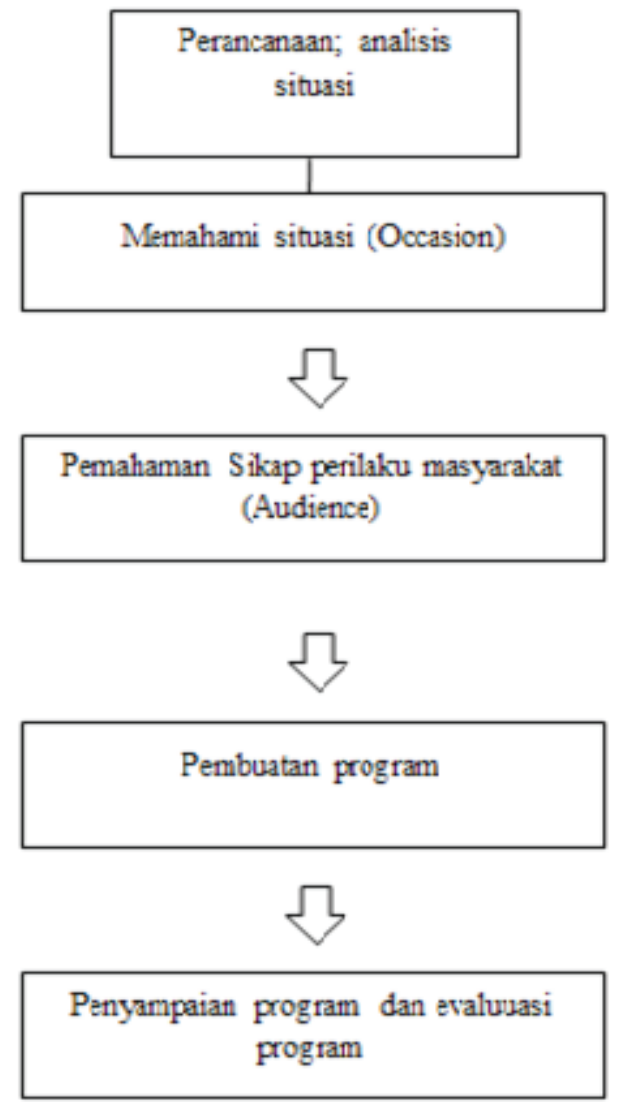

Sumber: Hasil penelitian, 2018

Gambar 1 Komunikasi Empati Public Relations PT Santos dengan Pendekatan Intercultural Communication

komunikasi langsung atau tatap muka Sejatinya pencapaian usaha public relations PT Santos dalam membangun hubungan baik dengan masyarakat Gili Genting, merupakan kepiawaian public relations dalam menjalankan peran dan fungsinya. Peran sebagai fasilitator komunikasi dalam praktiknya benar-benar diterapkan. Seorang fasilitator seyogyanya memahami situasi terlebih dahulu sebelum membuat program. Hal ini penting untuk memetakan partisipan dan tujuan kegiatan (Hidayat et al., 2017).

Pada bagian lain, peneliti juga menemukan 
tentang mekanisme kerja public relations PT Santos dalam membangun hubungan baik. Tahapan awal dalam langkah kerja public relations $\mathrm{PT}$ Santos adalah melakukan pendekatan persuasi dan pendekatan fungsional, yang di dalamnya melibatkan proses komunikasi empati.Tujuan dari kedua pendekatan tersebut yaitu untuk mengenal dan memahami lebih dalam tentang karakteristik budaya masyarakat Gili Genting. Hal ini sangat membantu upaya public relations dalam membangun hubungan baik. Public Relations memiliki sebuah peran yang di dalamnya terdapat sebuah tanggung jawab yang besar terhadap citra dan reputasi perusahaan (Gassing \& Suryanto, 2016). Untuk itu, public relations sebagai fungsi manajemen yang khas harus dapat mendukung pembinaan, pemeliharaan hubungan antara perusahaan dengan publiknya. Public relations adalah jembatan antara perusahaan dengan publik untuk mencapai saling pengertian (mutual understanding) antara kedua belah pihak. Public Relations dalam menjalankan fungsinya juga dituntut agar mampu mempertemukan keinginan perusahann dengan publiknya. Menurut Dozier dan Broom (dalam Gassing \& Suryanto, 2016), praktisi public relations diposisikan sebagai ahli dan menjadi penasihat bagi pimpinam organisasi. Peran sebagai penasihat meliputi memberikan masukan dan pertimbangan terkait public relations oses pembuatan keputusan. Public Relations menajdi fasilitator ketika menyelesaikan suatu masalah. Public Relations berperan sebagai fasilitator atau sebagai jembatan komunikasi antara organisasi dengan publik. Relations juga dapat menjadi leader dalam penanganan krisis. Public Relations dalam mengatasi sebuah krisis dengan membentuk manajemen khusus untuk menghadapi kemungkinan terjadinya suatu krisis (Management of Public Relations crisis) dimulai dari bagaimana menangani keluhan (handling of complaint), protes dan sebagainya. Kemudian public relations membentuk tim untuk menghadapi krisis, dari krisis kepercayaan (crisis of confidence), krisis manajemen (perusahaan yang tengah mengalami suatu krisis), atau proyek yang menimbulkan kecelakaan sehingga konsumen atau masyarakatnya menjadi korban (Jessica \& Ilfandi, 2018). Public Relations juga dinilai sebagai pelaksanaan teknis komunikasi yang menyediakan layanan dibidang teknispublic relations, bertindak sebagai komunikator perusahaan dan beruhubungan dengan publiknya (Dozier and Broomdalam Gassing \& Suryanto, 2016).

Membangun hubungan baik adalah suatu tanggung jawab besar bagi seorang public relations. Melalui hubungan tersebut akan tercermin citra positif perusahaan. Menurut Sutojo (dalam Rahmayani \& Silvana, 2018), 
beberapa manfaat mendapatkan citra yang positif bagi perusahaan antara lain daya saing jangka menengah dan panjang yang mantap (mid and long tern sustainable competitive position), menjadi perisai selama masa krisis (an insurance for adverse times), menjadi daya tarik eksekutif handal (attracting the best executives available), meningkatkan efektivitas strategi pemasaran (increasing the effectiveness of marketing instruments), penghematan operasional (cost savings). Demikian halnya yang terjadi pada peran public relations PT Santos. Ia senantiasa bertanggung jawab pada citra dan reputasi perusahaan. Ia juga harus mempertangung jawabkannya pada masyarakat Gili Genting sebagai masyarakat terdampak kegiatan operasional Santos. Dalam menjalankan fungsinya, public relations PT Santos secara total menyampaikan pesan, memberikan pemahaman, memahami situasi masyarakat, mendengarkan pendapat masyarakat, dan mengajak masyarakat dalam memahami situasi perusahaan.

Proses perencanaan kegiatan public relations $\mathrm{PT}$ Santos dalam membangun hubungan baik dengan masyarakat Gili Genting sangat membutuhkan peran empati didalamnya. Empati terjadi karena adanya keterbukaan public relations PT Santos dengan memberikan porsi atas keterlibatan masyarakat dalam mensosialisasikan kebijakan perusahaan.
Keterlibatan muncul sebagai konsep penting dalam public relations dengan maksud untuk membangun hubungan antara perusahaan dengan masyarakat (Johnston, 2014). Hal senada diungkapan Taylor (Taylor, Kent, Taylor, \& Kent, 2014) bahwa keterlibatan dapat dilakukan melalui dialog antara perusahaan dengan masyarakat. Dialog dimaksudkan untuk berempati dan mencoba memahami keinginan diantara keduanya sehingga menghasilkan kebersamaan.Empati merupakan salah satu modal terpenting dalam membangun suatu hubungan baik, dengan melibatkan nilai budaya didalamnya. Hal ini merupakan gardu utama public relations $\mathrm{PT}$ Santos dalam membentuk hubungan perusahaan dengan masyarakat Gili Genting demi sebuah kelancaran kegiatan perusahaan.

Komunikasi empati juga mampu mengubah kepercayaan, sikap, dan perilaku masyarakat untuk memahami dan menerima keberadaan PT Santos. Usaha dalam pendekatan tersebut bertujuan agar masyarakat Gili Genting dapat diajak bekerjasama dengan baik dalam proses kegiatan eksplorasi minyak bumi dan gas. Indikator lainnyaadalah gagasan publicrelations PT Santos bertekad untuk membuat masyarakat Gili Genting percaya tentang keberadaan Santos dapat memberikan keuntungan bagi masyarakat setempat.

Dalam upaya membangun hubungan baik, 
public relations $\mathrm{PT}$ Santos selalu berkoordinasi langsung dengan masyarakat setempat. Public Relations PT Santos menugaskan LSM sebagai mitra kerja untuk selalu menginformasikan kebijakan Santos kepada masyarakat. Pada pelaksanaannya, public relations PT Santos menggunakan dua pendekatan sebagai mekanisme kerja. 1) pendekatan persuasi, yaitu pendekatan secara langsung antara public relations $\mathrm{PT}$ Santos dengan masyarakat setempat. 2) Pendekatan fungsional, yakni melibatkan opionion leader sebagai juru bicara. Dalam hal ini bekerjasama dengan aparat desa setempat dan LSM terkait. Dalam teori public relations keterlibatan kelompok masyarakat disebut (community engagement). Keterlibatan masyarakat yang berhasil yaitu keterlibatan didasarkan pada informasi yang efektif, tepat, dan tepat waktu yang diberikan kepada anggota masyarakat. Hal ini dapat berupa penyebarluasan informasi kepada kelompok komunitas yang ditentukan sebelumnya. Sebagai strategi keterlibatan informasi, komunitas memberikan fakta, konteks, relevansi, atau posisi yang berkaitan dengan keputusan organisasi (Johnston, 2010). Hal ini pula yang dilakukan oleh public relations PT Santos. Mereka terlibat secara langsung di dalamnya untuk memberikan edukasi, sosialisai pada masyarakat, mengontrol, dan memonitoring aktifitas masyarakat nelayan di area operasional Santos. Mekanisme persuasi dilakukan dalam bentuk kegiatan nonfromal seperti keterlibatan public relations PT Santos dalam kegiatan sehari-hari masyarakat meliputi mencari ikan, mengolah ikan dan bahkan ikut terlibat dalam makan bersama. Mekanisme persuasi merupakan mekanisme yang bertujuan untuk mendekati masyarakat secara personal. Sedangkan mekanisme fungsional berupa kegiatan yang formal, seperti memberikan bantuan dana sebagai wujud kepedulian terhadap kesejahteraan dan kelestarian budaya dan lingkungan setempat. Jenis bantuan dapat dikategorikan sebagai bentuk kegiatan Corporate Social Responsibility (CSR). Corporate Social Responsibility merupakan suatu bentuk tindakan nyata perusahaan atau kepekaan dan kepedulian untuk berkontribusi terhadap lingkungan sosial dalam memberikan manfaat, menyelesaikan masalah, serta meningkatkan kualitas hidup masyarakat. CSR dapat dikatakan sebagai salah satu instrumen inovatif yang dapat membantu perusahaan untuk peka dan adaptif terhadap lingkungan dan kehidupan masyarakat (Fuad, Dida, \& Komariah, 2017).

Hasil temuan lainnya yaitu terkait dengan komponen pendekatan komunikasi empati public relations PT Santos. Pada dasarnya membangun suatu hubungan baik memerlukan suatu perencanaan di dalamnya. Perencanaan tersebut merupakan strategi aksi 
dan komunikasi di dalam setiap kegiatan public relations. Adapun komponenkomunikasi empati sebagai pendekatan dalam proses membangun hubungan baik yaitu, a) komponen kognitif, b) komponen afektif. Komponen kognitif terdiri dari pemikiran seseorang mengenai objek ternetntu, seperti fakta, pengetahuan, dan keyakinan, Sarwono (dalam Anggita \& Adha, 2010). Sedangkan komponen afektif terdiri dari perasaan positif atau negatif yang diasosiasikan dengan objek sikap. Komponen afektif meliputi bagaimana faktor emosi dan perasaan individu mempengaruhi sikap. Kedua komponen tersebut ada di dalam komunikasi empati public relations PT Santos. Pada prinsipnya, empati adalah pengalaman efektif. Dua komponen efektif diperlukan untuk terjadinya pengalaman empati, yaitu kemampuan untuk mengalami secara emosi dan tingkat reaktivitas emosional yang memadai, yaitu kecenderungan individu bereaksi secara emosional terhadap situasisituasi yang dihadapi, termasuk emosi yang tampak pada orang lain. Empati sebagai aspek afektif murujuk pada kemampuan menselaraskan pengalaman emosional pada orang lain. Berdasarkan asumsi Colley (dalam Hidayat, 2012) aspek empati ini terdiri atas simpati, sensitivitas, dan sharing. Empati efektif merupakan suatu kondisi dimana pengalaman emosi yang sedang dirasakan oleh orang lain, atau perasaan mengalami bersama dengan

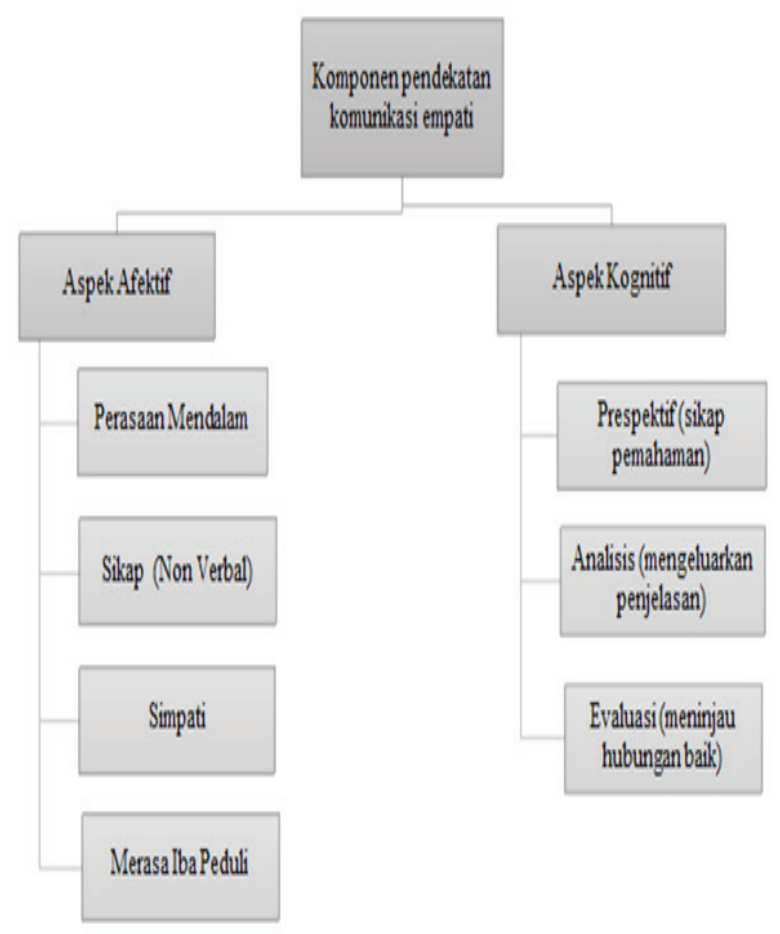

Sumber: Hasil Penelitian, 2018

Gambar 2 Komponen Pendekatan Komunikasi Empati Public Relations PT Santos

orang lain. Sikap ini menunjukan bahwa public relations $\mathrm{PT}$ Santos telah dianggap menghargai dan memahami masyarakat Gili Genting dalam kondisi sebagai masyarakat terdampak. Berikut ini merupakan hasil temuan terkait komponen komunikasi empati public relations PT Santos dalam membangun hubungan baik dengan masyarakat Gili Genting Madura. Pendekatan komunikasi empati public relations PT Santos sangat memperhatikan aspek afektif dan kognitif. Afektif meliputi perasaan, sikap, simpati, dan merasa iba atau peduli. Sedangkan aspek kognitif terdiri dari perspektif atau pemahaman, analisis atau penjelasan, dan evaluasi atau feedback suatu hubungan baik. Aspek kognitif menekankan pada perasaan 


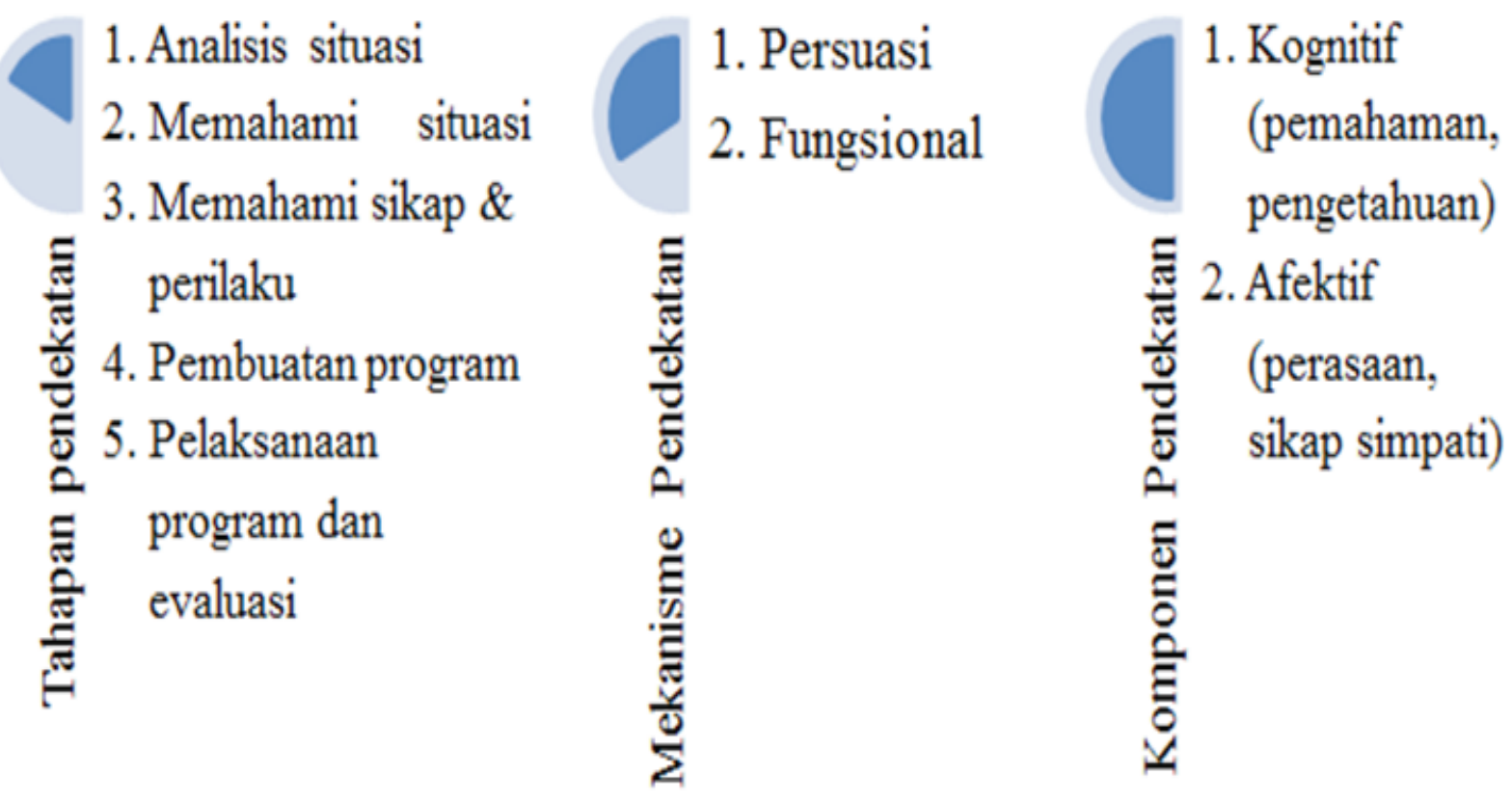

Sumber: Hasil Penelitian, 2018

Gambar 3 Pola Komunikasi Empati Public RelationsPT Santos dengan Pendekatan Intercultural Communication

atau situasi kejiwaan masyarakat Gili Genting Madura. Artinya bagaimana public relations PT Santos dituntut untuk mempelajari dan memahami situasi budaya masyarakat setempat. Hal ini dilakukan agar tidak ada kesalahan dalam melakukan komunikasi. Masyarakat Gili Genting dengan karakter yang khas, tentu saja membutuhkan teknik komunikasi berupa keterlibatan secara langsung di tengah-tengah aktivitas masyarakat. Sedangkan aspek kognitif dilandasi bahwa tujuan komunikasi empati adalah memberikan pemahaman, menjelaskan sehingga memperoleh perubahan perilaku positif dari masyarakat berupa dukungan. Perubahan dapat diukur melalui tahapan kontrol atau evaluasi yang dilakukan oleh public relations PT Santos secara berkesinambungan.
Perilaku komunikasi merupakan sebuah cermin yang tidak dapat disembunyikan ketika sedang berinteraksi secara dua arah. Perilaku merupakan sebuah modal dasar dalam prooses berinteraksi. Demikian pula halnya perilaku komunikasi masyarakat sebagai salah satu komponen komunikasi empati. Perilaku berupa dukungan tentu saja yang diharapkan dalam membangun hubungan baik. Dalam suatu hubungan akan terjalin dengan baik jika perilaku komunikasi juga terjadi dengan baik. Menjadikan suatu hubungan untuk saling menerima dan saling menghargai satu sama lainnya.

Karakter budaya yang dimiliki oleh masyarakat Gili Genting mendorong public relations PT Santos untuk membuat strategi komunikasi empati. Tentu saja hal ini merupakan 
langkah yang tepat dalam mendapatkan kepercayaan dari masyarakat Gili Genting. Strategi komunikasi yang menekankan pada pendekatan budaya lokal. Budaya merupakan suatu hal yang sangat dihargai oleh masyarakat Gili Genting. Bagi mereka, budaya adalah suatu kehidupan yang menjadi ciri khas karakter Masyarakat Madura. Berikut ini pola komunikasi empati public relations PT Santos dengan menggunakan pendekatan intercultural communication.

Komunikasi empati public relations bertujuan untuk membentuk citra positif PT Santos dimata masyarakat setempat. Komunikasi yang dibangun dengan memperhatikan dan mempertimbangkan unsur budaya lokal. Masyarakat Gili Genting Madura masih sangat dipengaruhi oleh budaya sehingga pemikiran, sikap dan perilaku mereka selalu mencerminkan entitas lokal. Untuk itu, public relations $\mathrm{PT}$ Santos senantiasa menjaga pola komunikasi empati sebagai kekhasan dalam berkomunikasi. Komunikasi empati dengan memperhatikan aspek pendekatan, mekanisme dan komponen komunikasi. Pendekatan komunikasi selalu diawali dengan kegiatan analisis situasi. Kegiatan ini bertujuan untuk mengetehui dan memahami siapa saja yang akan dilibatkan sebagai publik atau partisipan. Selain itu, analisis situasi juga dimaksudkan untuk mengetahui tujuan kegiatan sehingga dapat membantu dalam memetakan program strategik. Selanjutnya adalah memperhatikan aspek mekanisme komunikasi empati Mekanisme bertujuan untuk mengetahui bentuk kegiatan yang tepat diterapkan pada kegiatan sosialisasi. Mekanisme komunikasi empati memetakan bentuk kegiatan, tema dan juga pesan yang akan disampaikan. Mekanisme komunikasi empati public relations PT Santos terdiri dari persuasi yang ditujukan secara person to person. Sedangkan mekanisme fungsional difokuskan pada institusi atau lembaga yang dapat dijadikan sebagai opinion leadar. Bentuk kegiatan untuk mekanisme fungsional biasanya berupa Corporate Social Responsibility (CSR). Tahapan berikutnya yakni memperhatikan komponen komunikasi empati. Komponen terdiri dari kognitif dan afektif. Komponen ini mengacu pada hasil akhir dari pelaksanaan kegiatan sosialisasi yang dilakukan oleh public relations PT Santos. Pelaksanaan dengan tujuan mampu memberikan pengetahuan, pemahaman kepada masyarakat setempat. Adanya pemahaman tersebut diharapkan dapat mendorong sikap dan perilakumasyarakat berupa dukungan terhadap kegiatan PT Santos. Adanya dukungan, artinya masyarakat setempat percaya bahwa keberadaan PT Santos dapat memberikan manfaaat bagi masyarakat. Sikap saling percaya tentu saja menjadi modal utama dalam membangun hubungan baik, yaitu 
hubungan antara public relations PT Santos dengan masyarakat Gili Genting Madura. Hubungan yang dimaksud adalah hubungan berbasis budaya atau relasi budaya.

\section{SIMPULAN}

Pendekatan Intercultural Communication Public Relations PT Santos dalam membangun komunikasi empati dengan masyarakat Gili Genting Madura, didasarkan pada itikad keduanya untuk membangun hubungan baik. Hubungan tersebut dibangun melalui komunikasi empati, yaitu komunikasi yang menekankan sikap saling terbuka, saling percaya dan menghargai. Komunikasi empati public relations PT Santos selalu mengganggap bahwa budaya sebagai konteks yang diperhitungkan dalam berkomunikasi. Setiap tahapan komunikasi empati selalu mempertimbangkan aspek budaya lokal.

Masyarakat Gili Genting Madura memiliki kekhasan budaya dengan menjunjung tinggi nilai kolektivitas yang dikenal dengan budaya gotong royong. Adapan pendekatan yang digunakan yakni melalui keterlibatan secara langsung public relations terhadap setiap kegiatan masyarakat setempat. Karenanya dalam menerapkan komunikasi empati, public relations PT Santos senantiasa merumuskan beberapa aspek meliputi tahapan pendekatan, mekanisme pendekatan, dan komponen pendekatan. Tiga aspek komuikasi empati tersebut saling berkaitan sehingga mampu menghasilkan hubungan baik antara public relations PT Santos dengan masyarakat terdampak yaitu masyarakat Gili Genting Madura.

Hasil penelitian ini juga menemukan bahwa jenis kegiatan yang diberikan kepada masyarakat belum bervariasi sehingga terkesan monoton. Diharapkan dalam melakukan tahapan pendekatan berupa analisis situasi, public relations $\mathrm{PT}$ Santos mampu menemukan data sebagai dasaryang kuat dalam membuat program yang sangat dibutuhkan oleh masyarakat Gili Genting. Untuk itu, analisis situasi tidak dilakukan dalam waktu yang relatif singkat, akan tetapi dilakukan secara berkesinambungan dalam kurun waktu yang relatif lama. Dengan demikian akan menghasilkan data yang lebih akurat dan komprehensif. Bahkan jauh lebih baik apabila kegiatan analisis tersebut melibatkan pihak eksternal sehingga proses analisis situasi akan lebih netral dan independen.

\section{DAFTAR PUSTAKA}

Anggita, I., \& Adha, N. (2010). Sikap dan Intensi Pemanfaatan Internet dalam Kegiatan Bisnis: The Attitude and Intention of Internet Utilization for Bussines. Jurnal Sosiologi Pedesaan (Sodality), 04(03), 380-389.

Ardianto, E. (2013). Handbook of public relations; pengantar komprehensif. 
Bandung: Simbiosa Rekatama Media.

Fuad, A. V., Dida, S., \& Komariah, K. (2017).

Health agent award sebagai corporate social responsibility PT Nutrifood Indonesia. Jurnal Ilmiah Ilmu Hubungan Masyarakat (Profesi Humas), 2(1), 37-44.

Gassing, S., \& Suryanto. (2016). Public relations. Yogyakarta: ANDI OFFSET.

Grunig, J. E. (2010). Journal of public relations furnishing the edifice : ongoing research on public relations As a Strategic Management Function. Journal of Public Relations Research, (September 2013), 37-41. http:// doi.org/10.1207/s1532754xjprr1802

Hidayat, D. (2012). Komunikasi antarpribadi dan medianya. Yogyakarta: Graha Ilmu.

Hidayat, D. (2014). Media public relations. Jogjakarta: Graha Ilmu.

Hidayat, D., Kuswarno, E., \& Zubair, F. (2017). THE IPPAR model sebagai komponen etnografi pr pada kajian public relations berbasis budaya. Ilmu Komunikasi UPN Veteran Jogjakarta, 15(April), 60-72.

Hidayat, D., Kuswarno, E., Zubair, F., \& Hafiar, H. (2018). Public relations communication behavior through a local-wisdom approach : the findings of public relations components via ethnography as methodology. Malaysian Journal of Communication, 34(3), 56-72.

Hidayat, D., \& Suhartini, T. (2018). Community empowerment dan product branding “ SEKHUIT ." Jurnal Ilmu Komunikasi Efek (JIKE), 1(2), 41-58.

Ibrahim, I. S. (2004). Sirnanya komunikasi empatik. Bandung: Pustaka Bani Quraisy.

Jandt, F. E. (2013). An Introduction to Intercultural Communication; Identities in a Global Cummunity. SAGE Publication.

Jessica, S., \& Ilfandi, A. (2018). Aktivitas public relations Angkasa Pura II dalam menangani pemberitaan negatif terminal 3 bandara
Soekarno-Hatta the activity of public relations of Angkasa Pura II in handling negative tews terminal 3 Soekarno - Hatta Airport. Jurnal Ilmiah Ilmu Hubungan Masyarakat (Profesi Humas), 2(2), 119135.

Johnston, K. A. (2010). Community engagement: Exploring a relational approach to consultation and collaborative practice in Australia. Journal of Promotion Management, 16(1-2), 217-234. http://doi. org/10.1080/10496490903578550

Johnston, K. A. (2014). Public relations and engagement: theoretical imperatives of a multidimensional concept public relations and engagement: theoretical imperatives of a multidimensional concept. Journal of Public Relations Research, (November). http://doi.org/10.1080/10627 26X.2014.959863

Ma'arif, S. (2015). The history of MADURA. Yogyakarta: Araska.

Makmun, S. (2013). Memahami orang lain melalui keterampilan mendengar secara empatik. HUMANIORA, 4(45), 422-431.

Morrisan. (2008). Manajemen public relations. Jakarta: Prenada Media Group.

Rahmayani, R., \& Silvana, H. (2018). Program corporate social responsibility (csr) pada PT Indocement Tunggal coprporate social responsibility ( $\mathrm{csr}$ ) programs in PT Indocement Tunggal. Jurunal Ilmiah Hubungan Masyarakat (Profesi PR), 2(2), 186-202.

Rodríguez-salcedo, N., \& Gómez-baceiredo, B. (2017). A herstory of public relations : teresa dorn, from scott cutlip to bursonmarsteller europe (1974 - 1995) a herstory of public relations: Teresa Dorn, from Scott Cutlip to. Journal of Public Relations Research, 29(1), 16-37. http://doi.org/10.1 
080/1062726X.2016.1271983

Ruslan, R. (2015). Metodelogi penelitian public relations dan komunikasi. Depok: Rajawali Pers.

Sentosa, A. T. (2015). Pola komunikasi dalam proses interaksi sosial. Ilmu Komunikasi, 3(3), 491-503.

Taylor, M., Kent, M. L., Taylor, M., \& Kent, M. L. (2014). Dialogic engagement: clarifying foundational concepts. Journal of Public Relations Research, (November),
37-41. $\quad$ http://doi.org/10.1080/106272 6X.2014.956106

Wirtz, J. G., \& Zimbres, T. M. (2018). A systematic analysis of research applying ${ }^{6}$ principles of dialogic communication' to organizational websites, blogs, and social media : Implications for theory and practice media: Implications for theory and practice. Journal of Public Relations Research, 00(00), 1-30. http://doi.org/10.1 080/1062726X.2018.1455146 